\section{Girainal Communiations.}

\section{ON TUE TREATMENT OF ACUTE RIIEUMATISA.}

\section{By Trouras Ixyax, M.D., Liverpool.}

Ox rearling Dr. Fuller's work on Rheumatism, I have met with so many statements at variauce with my own experience of the disease, that I think it right to give sume uecount of the complaint as we have it here, and the ctiect of the trentment adopted. A difference so wide hetween my own cases and those reported in London and elsew!ere, can only be accounted for on the sumposition that there is some essential difference in the complaints described; or, which scarcely scems probable, that there is some error in description and treatment.

Iy own experience of rhenmatic ferer commencel in Lon don, at hing's College llospital, where 1 for some time ofliciated as clinicul clerk to Dr. Budd; and I have a very vivid recollection of the cases we met with there, and the long discussions that were held upon the proper plan of trentment. I increased my acquaintance with the disease when houscsurgeon to the Intirmary in this town. Since my appointment of physician to the Northern Hospital, I have had about thirty cases under my care, which have varied greatly in intensity, etc.

Dr. Fuller gives as the average duration of his cases fire wecks. 'The average cluration of those I have treated has lieen about $t c n$ days. The longest case I have hal has been three weeks. Dr. Fuller states that he has found those cases progress the most favourably in which the sour-smelling perspirations are most abundant. On the contrary, I have found that these cases resist treatment the longest, and that relief is proportionate to the diminution of the sweating. I am, however, bound to add as a signiticant fact, that the smell of the perspiration in my cases has never equalled that with which I was familiar in London, und that profuse sweating is quite the exception with us; and a dry skin, and comparatively clean tongue, the rule.

Dr. Fuller considers it advisable to give a duily aperieut. I have never found it necessary to interfere with the bowels in any way.

Dr. Fuller has tried lemon-juice in thirty cases, and only found it do good in three. I have trierl it in an equal number, and found it do good in all. Our last two junior house. surgeons came down fresh from London undervaluing it: one of them renarking in a patronising tone, when he heard me order lime-juice for rheunatic fever-" Do you still believe in that drug here?" MIy reply was: "Yes; and you will do so to by-and-bye." My prophecy was soon fultilled; and buth became enthusinsts in its fuvour.

As it would be tedious to go into the details of every case, I may sum up by giving an account of the routinc treatment now adopted. I began by giving the common commercial lime-juice in every case in doses of half an ounce evely tour hours, bit was rather disappointed with the results: the dose was then increased to an ounce, and the effects were very markel ; relief was commonly experienced in twenty-four hours ; and I have repeatedly seen a mun, so severely attacked that all motion was intensely painful on Monday, walking about the wards convalescent on the Friday in the same week! In very bad cases, attended with immoderate swenting, the inprovement is rurely well marked until the end of the first week; and the first good sign is the skin becoming drier.

I have only had two cases of cardiac complication: in the first, the rheumatic fercr was severe, but the patient was con. valescent and walking about the wards on the fourth day. He slept near a door, and complained of having taken cold on the cighth day after admission; and on examination, 1 tound a systolic vellows-sound, best heard at the apex of the h(art. He had no retum of the rhenmatic pains. The disense of the heart was soon subdued. The second case was one where the cardiac disease precelled the other symptoms for three days.

In all cases at the present time, as soon as the disease shows itself as acute rheumatism, the patient is ordered to take as much lime-juice as he comfortably can; and the minimum is to be an ounce every three hours. If any of the small joints-as the hand, foot, wrist, or ankle-are inflamed, a few leeches are applied, which give instant and permanent relief. If no sleep is obtained, a dose of morphis is given at bed-time. I have never been able to find any other result from the lime-juice than a steady dimiuntion of the severity of fever, pain, and swenting, when present. 'I'he diet depends upon the patient's appetite. No other medicines are given, beyond those mentioned above. $U_{p}$ to the present time, no patient has yuarrelled in any way with the lime-juice; nor have I had oceasion to loubt its value. Is its success has been so marked, and as there is great reason to believe that much of what we purchase for lime.juice is manufactured, it is my intention, when I have another case, to try the intluonce of citric, tartaric, and other veretable acids.

(I) the modus operandi of the acid, I can form no idea. To assume that it assists in the oxygenation of lactic acid, is to asisume that lactic acid is the canse of rheumatic fever, and that its oxide is less potent than the acid itseli-n thing of which we have not the finintest ruliable proot: $A$ s to the poison being eliminated under the nse of lime-juice, there: is not tho smallest evidence, nor is there any more that it is destroyed in the system.

With so comparatively few rases, I have no light to genernlise, nor do 1 feel disposed to do so, as I ain aware that future cases muy oceur that will force me to lose contidence in my present plan. Of one thing I however do feel errtain, as much from analogy as from gtneral exprerience; viz., that tho less rheumatic patients are pulled down by depressing remedies, the more rapid will be the reenvery, and the less the danger of eardiac or other complications.

\section{TR HAT M E T OF SCAL P-IV OU N D S.}

By Troaras P. Mr. O'Duxoras, Esil., Maytield.

TнF practice of using sutures in sealp.womls ubtains to thi.3 day, in mining practice, and is attended with sucress; but the same surgeon who adopts this practice in a ruial district would not do so in towns.

I have used snceessfully a very simple method of coaptation, which is as follows:- - . Cut oft the hair at the edres of the wound, over a space of about one tenth of an inch, at each side of the cut. 2. 'Tie some of the opposite hairs together. 3. If the hair be too short, tie some pieces of thrend to the roots. If the hair be very long, as in a temale, it probably need not be cut at all, as it can easily be prevented from intruding into the wound.

The following case was thus treated:-

C.ss. A. 13., aged about 5 (), an able-bodied miner, received a sealp-wound from a fall of a large mass of eartlı. 'The wound was somewhat rectangulur, being about four inches in vertical by six in horizontal extent, deunding portions of the frontal, parietal, and temporal bones. On turning back the flap, the surface of the calvarium was found thickly covered with loam and schist. There was an obovate aperture, equal to about a square inch, in the squamous portion of the temporal bone, about two inches above the concha, and parallel with its posterior edge. From the posterior mar fin of the aperture rongh ligamentous-looking tissue proceeded forwards and inwards, apparently to be attacbed to the dura mater, between which and the cranium were several pieces of schist.

The patient, when I saw him, was sitting in a chair. His general aspect was that of a person much fatigued. The tem. perature of the skin, and sensation, were natural. The pulse was natural, and the tongue clean. No symptoms were presented by the head, chest, or abdomen. The limbs were weak. 'The liganentous-looking formation showed that the osseous injury was of remote date. 'The man was in perfect possession of his mental faculties, and informed me that his "skull hal been hroken some years ago, and it was likely I might now see a hole in his head."

The removal of the loam and schist was tedious, owing to the minute particles of schist being embedded on aud adliering closely to the cranium, and being deep!y imberlded in the angles of the wound. A few fiagments lying between the dura mater and cranium were removed. The scalp was readjusted, and rules 1 and 3 were put in practice.

Immediately after readjustment, the hair being combed over the wound, no injury was discernible-obviously a deside ratum, especially when ladies are concerned. 'The wound healed rapidly by the first intention.

liemarks. With regard to the use of sutures, accurate adjustment and not traction should be their olject. If traction be used (unless it be very trifling) the result will be ulceration 